
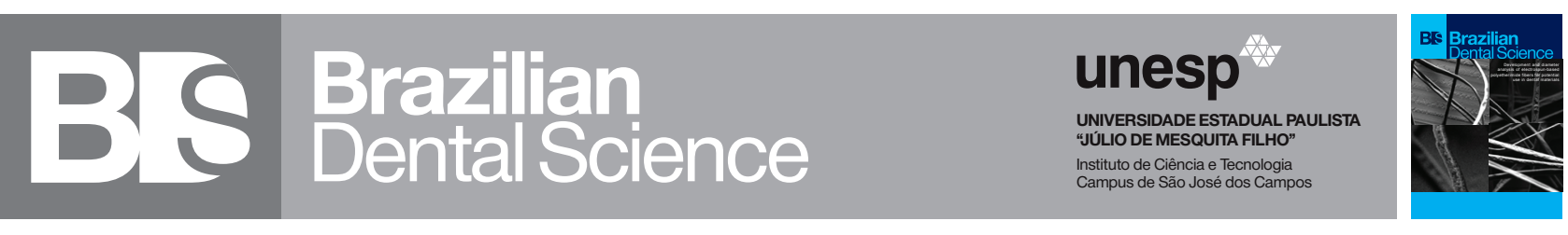

\title{
Bolton tooth size analysis in a sample of Sudanese adults
}

\section{Análise de Bolton do tamanho dentário em uma amostra de adultos sudaneses}

\author{
Raja AbdAlgadir MUSTAFA ${ }^{1}$, Amal Hussein ABUAFFAN ${ }^{2}$ \\ 1 - Orthodontic department, Al Neelain University, Khartoum, Sudan. \\ 2 - Department of orthodontics, Pedodontics and preventive dentistry, University of Khartoum, Khartoum, Sudan.
}

\section{ABSTRACT}

Introduction: A correct proportion between the upper and lower teeth is critical to achieving proper occlusal interdigitation, ideal overjet, and good molar intercuspation at the end of orthodontic treatment. Objectives: To determine the anterior and overall Bolton's ratio in the Sudanese population, investigate gender differences in tooth size ratios, and to compare these results with Bolton's original ratio norm. Material and Methods: The sample consisted of dental casts of 104 Sudanese University students with normal occlusion (52 females, 52 males), aged between 16-26 years randomly selected from AL- Neelain University. An electronic digital caliper was used to measure the mesiodistal tooth size of the maxillary and mandibular teeth anterior to the second molars. These measurements were then used to obtain Bolton's ratio. Mean, range, and standard deviation of the anterior and overall ratios were computed for each subject. T-Tests were used to compare gender differences and to investigate differences between the results of this study and Bolton's original ratio. Results: Anterior and overall Bolton ratios for males were $78.43 \pm 2.44$ and 93.901 \pm 9.8 and for females were $78.29 \pm 2.6$ and $91.67 \pm$ 3.3 percent, respectively. There were no statistically significant differences between males and females for the anterior and overall ratios $(\mathrm{P}>0.05)$. The anterior and overall Bolton's ratios among Sudanese University students were $78.37 \pm 2.54$, and $92.79 \pm$ 7.43 percent, respectively. A statistically significant difference between this study and Bolton's study was found in both anterior and overall ratio $(\mathrm{P} \leq$ 0.05). Conclusion: Bolton's mean ratios may not be applicable to the Sudanese population.

\section{KEYWORDS}

Bolton's ratio; Sudanese population; tooth-size.

\section{RESUMO}

Introdução: Uma proporção correta entre os dentes superiores e inferiores é crítica para alcançar a interdigitação oclusal adequada, overjet ideal e boa intercuspidação molar ao final do tratamento ortodôntico. Objetivos: determinar a proporção anterior e geral de Bolton na população sudanesa, investigar as diferenças de gênero nas proporções de tamanho dos dentes e comparar esses resultados com a norma original de Bolton. Material e Métodos: A amostra foi constituída por modelos de gesso de 104 universitários sudaneses com oclusão normal (52 mulheres, 52 homens), com idades entre 16-26 anos, selecionados aleatoriamente na Universidade AL-Neelain. Um paquímetro digital eletrônico foi usado para medir o tamanho mesiodistal dos dentes superiores e inferiores anteriores aos segundos molares. Essas medidas foram então usadas para obter o índice de Bolton. Média, intervalo e desvio padrão das relações anterior e geral foram calculados para cada amostra. Os testes $t$ foram usados para comparar as diferenças de gênero e para investigar as diferenças entre os resultados deste estudo e a proporção original de Bolton. Resultados: Os índices de Bolton anterior e geral para homens foram 78,43 \pm 2,44 e 93,901 \pm 9,8 e para mulheres foram 78,29 $\pm 2,6$ e $91,67 \pm 3,3$ por cento, respectivamente. Não houve diferenças estatisticamente significativas entre homens e mulheres para os índices anterior e geral $(P>0,05)$. Os índices de Bolton anterior e geral entre os estudantes da Universidade sudanesa foram 78,37 $\pm 2,54$ e 92,79 $\pm 7,43$ por cento, respectivamente. Uma diferença estatisticamente significativa entre este estudo e o estudo de Bolton foi encontrada na proporção anterior e geral $(P \leq 0,05)$. Conclusão: os índices médios de Bolton podem não ser aplicáveis à população sudanesa.

\section{PALAVRAS-CHAVE}

Índice de Bolton; População sudanesa; Tamanho do dente. 


\section{INTRODUCTION}

$\mathrm{T}$ he majority of the demand for orthodontic treatment arises because the teeth are a decorative component of the face [1]. The size of the teeth and dental arches have significant implications in orthodontic diagnosis and treatment planning, affecting the space available, dental aesthetics, and stability of the dentition. These factors should be considered while planning an orthodontic treatment to determine the requirements for inter-dental stripping, crown re-contouring, prosthetic reconstruction or extraction, and to avoid compromising the final results [2].

The importance of having a certain relationship between the maxillary and mandibular teeth drew the attention of the investigators over the years. Without a correct match of the mesiodistal widths of the maxillary and mandibular teeth, it is difficult to obtain an ideal overjet, overbite, and a proper occlusion during the final stages of orthodontic treatment $[3,4]$. The absence of Tooth Size Discrepancy (TSD), had been considered the seventh key to normal occlusion [5]. The mesiodistal tooth-size of the maxillary and mandibular arches must relate to each other to obtain an optimal occlusion at the completion of orthodontic treatment. If a patient has a significant (TSD), orthodontic alignment into optimal occlusion may not be possible [4]. A large percentage of orthodontic patients possess significant tooth-size discrepancies [6]. Therefore, orthodontists should be aware of these discrepancies before beginning orthodontic treatment [4]. The presence of (TSD) should be identified during the initial diagnosis and treatment planning stage. Thus appropriate mechanisms can be applied for resolving the discrepancy [7]. The treatment alternatives for tooth-size discrepancies include the restoration of relatively small teeth, interproximal stripping of relatively large teeth, modification of crown angulations or inclination, and extraction [4].
The perfect percentage of the upper and lower tooth material had been suggested by several studies [7-10]. Among these, Bolton's ratios are the most usually used methods to decide inter-arch (TSD) in orthodontic patients [11].

Bolton's [10] (1958) developed a method for evaluation of maxillary to mandibular toothwidth proportions based on 55 subjects with excellent occlusions. He developed two ratios for estimating (TSD). The anterior Bolton's ratio is obtained by dividing the mesiodistal size of the six mandibular anterior teeth (canine to canine) by the mesiodistal size of the six maxillary anterior teeth; the total Bolton ratio is obtained by dividing the mesiodistal size of the 12 mandibular teeth (first molar to the first molar) by the mesiodistal size of the 12 maxillary teeth. The ratios concluded from Bolton's study for a correct occlusion were anterior Bolton ratio $=$ $77.2 \%$, SD 1.65, and total Bolton ratio $=91.3 \%$, SD 1.91.

The incidence of (TSD) has been found to vary between different racial and population groups (Table V). Smith et al. [12] found significant differences in Bolton's overall and anterior ratios between Caucasians, Blacks, and Hispanics and suggested that population-specific standards are essential for clinical assessments. Lavelle [13] studied tooth-size ratio in different racial groups (Caucasoids, Mongoloids, and Blacks; 40 cases in each group). He noticed that the overall and anterior ratios were greater among blacks than Caucasoids, whereas the Mongoloids were intermediate. Therefore, different racial groups must be treated according to their characteristics [14].

Most research on (TSD) investigated the effect of sexual dimorphism. They did not, however, demonstrate a common trend, with most of the studies finding no differences in the prevalence of TSD between males and females [11,15-20]. 
There are very few studies $[4,21]$ that had been conducted on the intermaxillary tooth-size ratio (Bolton's ratio) in the Sudanese population. However, a firm conclusion is challenging to draw from these studies since their sample is not representative of the Sudanese population. Hence, the objectives of this investigation were: 1- To establish Bolton's overall and anterior ratio among a sample of Sudanese population (University Students). 2- To investigate any significant difference between males and female's subjects. 3- To compare the results obtained from this study with Bolton's original research and other studies in different populations.

\section{MATERIALS AND METHODS}

This descriptive-analytical, cross-sectional study was carried out in the capital city of the Republic of Sudan (Khartoum), for university students of Al- Neelain University. The students were selected using the following inclusion criteria.

- The subject had to be Sudanese.

- Male and Female aged 16-26 years old.

- The subject had Angle's Class I molar and canine relationship bilaterally.

- Dental arches with well-aligned teeth and space discrepancy of $0 \pm 3 \mathrm{~mm}$.

- Normal overjet and overbite $(2 \mathrm{~mm} \pm 1 \mathrm{~mm})$.

- All teeth were present and fully erupted from the first right molar to the first left molar.

- No dental anomalies.

- No evidence of tooth wear lesions, e.g., attrition.

- No interproximal caries or restorations.

- No previous or ongoing orthodontic treatment.

- No prosthetic tooth replacements or crowns.

\section{Sample size}

The following equation calculated the study sample:

$$
n=\left(\frac{Z s}{e}\right)^{2} \text { deff }
$$

Where:

$\mathrm{Z}=$ critical value from a standardized normal distribution that achieves (1- $\alpha$ ) \% confidence level $\mathrm{z}=1.96$ for $95 \%$ confidence level.

$\mathrm{S}=$ standard deviation.

$\mathrm{e}=$ margin of error in mean $(5 \%$ of the mean)

$$
\begin{aligned}
& \text { deff }=\text { design effect } \\
& \text { deff }=2
\end{aligned}
$$

Mean and standard deviation was obtained from a previous study [22] as follow

$\mathrm{SD}=3$.

$$
\begin{aligned}
& \text { mean }=23.8 \\
& \mathrm{e}=0.05 * 23.8 \\
& \mathrm{n}=\frac{1.96^{2} * 3^{2}}{(0.05 * 23.8)^{2}} * 2=52
\end{aligned}
$$

The sample size was equal to 52 . Therefore, the overall sample became 104 (52 males and 52 females).

\section{Study design:}

A cluster sample technique was used for the selection of faculties. As, a result, ten out nineteen faculties of Al Neelain University were selected. Then a simple random method was followed for the selection of students within each chosen faculty.

\section{Methodology}

Ethical approval was obtained from the Central Institutional Review Board at Al- Neelain University. Written consent was also obtained 
from the students who participated in this study. Students were free to attend or refuse participation even if they met all of the criteria necessary. The risks involved and the privacy terms were explained for the students inside the lecture room.

The initial screening for the students was carried out by the principal investigator (R.A.M) under natural light illumination. The examination was conducted for each student to determine if the participant meets all the inclusion criteria. The procedure comprised an intraoral inspection of the teeth and occlusion.

After, the selected students that fulfill the research criteria were recalled for impression taken, which was performed in the dental clinic of faculty of dentistry at AL- Neelain using alginate hydrocolloid impression material (ALGINMAX) that was mixed according to manufacture instruction with the help of a dental assistant. After that, upper and lower impressions were taken for selected students by the principal investigator (R.A.M). To ensure dimensional stability, the impressions were covered with damp gauze, during the short interval between the impressions were taken, and the pouring of the models. The models were poured immediately after taking the impressions using dental stone (OrthoStone) with the aid of a dental technician. Care was taken to avoid air bubbles and defective borders or breakages. Casts were then labeled appropriately for easy identification.

\section{Measurements}

The measurements of teeth were carried out using electronic digital calipers $(0-150 \mathrm{~mm}$ 16 " X0.01 JAPAN) that provided a precision reading to the nearest $0.01 \mathrm{~mm}$. The mesiodistal crown width was measured as the greatest distance between the contact points of the proximal surfaces of the dental crown, with the calipers parallel to the occlusal and buccal surfaces [23]. All measurements were made by principle investigator (R.A.M).
The mesiodistal width of anterior and posterior teeth up to permanent first molars were measured in the maxillary and mandibular arch. Bolton's overall and anterior ratios for each model pair was calculated using the following equations [10]:

Overall ratio $=$ sum of the mesiodistal diameter of 12 mandibular teeth/sum of the mesiodistal diameter of 12 maxillary teeth $\mathrm{x} 100$.

Anterior ratio $=$ sum of the mesiodistal diameter of 6 mandibular teeth/sum of the mesiodistal diameter of 6 maxillary teeth $\mathrm{x} 100$.

\section{Measurement Errors}

To assess the error of the method, the mesiodistal width of maxillary and mandibular teeth of 25 randomly selected subjects were re-measured and the differences in the measurements were analyzed using the intraclass correlation [24] to calculate the systematic error and Dahlberg's formula [25] to assess the casual error.

\section{Statistical analysis}

Statistical analysis was carried out using SPSS 20 analytic software. Q-Q Plot test and histogram showed a regular frequency distribution, so parametric statistical tests were used. An independent sample t-test was used to measure differences between genders, and a one-sample t-test was used to compare the intermaxillary ratio of this study and Bolton's original research. Significance was set at the $5 \%$ level ( $\mathrm{p} \leq 0.05)$ The individual data were summarized as ranges and mean values of these ratios. Variations were analyzed as coefficients of variation, standard deviations, mean, and range.

\section{RESULTS}

\section{Error of the Method}

Dahlberg's method (Table I) was used for analyzing the causal error, Dahlberg's revealed that the upper right first molar exhibited the 
highest error $(0.430 \mathrm{~mm})$, whereas the lower left central incisor demonstrated the lowest error $(0.177 \mathrm{~mm})$. The systematic error assessed by intraclass correlation ICC (Table II) showed that all measures are significant $\mathrm{p} \leq 0.05$, indicating high reliability of measures.

Table I - Error of the method for individual tooth width by Dahlberg's method $(n=25)$ *

\begin{tabular}{|c|c|c|c|c|}
\hline & $\begin{array}{l}\text { Upper } \\
\text { Right }\end{array}$ & $\begin{array}{l}\text { Upper } \\
\text { Left }\end{array}$ & $\begin{array}{l}\text { Lower } \\
\text { Right }\end{array}$ & $\begin{array}{l}\text { Lower } \\
\text { Left }\end{array}$ \\
\hline Central incisor & 0.178 & 0.188 & 0.201 & 0.177 \\
\hline Lateral incisor & 0.204 & 0.285 & 0.207 & 0.214 \\
\hline Canine & 0.249 & 0.240 & 0.220 & 0.204 \\
\hline First premolar & 0.198 & 0.194 & 0.214 & 0.217 \\
\hline $\begin{array}{l}\text { Second } \\
\text { premolar }\end{array}$ & 0.203 & 0.258 & 0.266 & 0.282 \\
\hline First molar & 0.430 & 0.413 & 0.279 & $\begin{array}{c}0.274 \mathrm{n}= \\
\text { sample size, } \\
\text { *measu- } \\
\text { rement in } \\
\text { millimeter }\end{array}$ \\
\hline
\end{tabular}

$\mathrm{n}=$ sample size, ${ }^{*}$ measurement in millimeter

Table II - Error of the method for total teeth width by Intraclass correlation $(n=25)$

\begin{tabular}{|ccc|}
\hline Variable & ICC & P-value \\
\hline Total teeth width in the maxilla & 0.879 & $0.000^{\star}$ \\
\hline Total teeth width in the mandible & 0.793 & $0.000^{*}$ \\
\hline
\end{tabular}

* Significant at $p \leq 0.05$

\section{Tooth size ratio in Sudanese population}

Of the 104 students, 52 (50\%) were females, and 52 (50\%) were male. The age of the male students ranged from 16-26 years (Mean $20.5 \pm$ SD 2.2) and in females ranged from 1824 years (Mean $19.6 \pm$ SD 1.4).

Bolton's anterior and overall ratio in male and female Sudanese university students are summarized in Table III and Table IV. The independent t-test showed that there was no difference between the tooth size of the male and female subjects (Table III).
Table III - Comparison of overall and anterior ratios mean values of the present study between males and females

\begin{tabular}{ccccccc} 
Ratio type & Gender & $\begin{array}{c}\text { Sample } \\
\text { size }\end{array}$ & Mean & SD & Range & P-value \\
\hline \multirow{2}{*}{ Anterior ratio } & Males & 52 & 78.435 & 2.447 & $73.25-84.97$ & 0.785 \\
& Female & 52 & 78.298 & 2.656 & $72.26-86.92$ & \\
& Males & 52 & 93.901 & 9.888 & $87.58-162.53$ & 0.127 \\
Overall ratios & Female & 52 & 91.674 & 3.359 & $81.16-103.68$ & \\
& & & & & &
\end{tabular}

* Significant at $p \leq 0.05, \mathrm{SD}-$ Standard deviation

Table IV - Bolton overall ratio and anterior ratio for males and females combined

\begin{tabular}{|cccccc|}
\hline Ratio type & Mean & SD & Range & $\begin{array}{c}\text { CV } \\
\text { (\%) }\end{array}$ & $\begin{array}{c}\text { Sample } \\
\text { size }\end{array}$ \\
\hline Anterior ratio & 78.37 & 2.54 & $72.26-86.92$ & 3.2 & 104 \\
\hline Overall ratios & 92.79 & 7.43 & $81.16-162.53$ & 8.0 & 104 \\
\hline
\end{tabular}

SD - Standard deviation, CV - Coefficient of Variation

The one-sample t-test was used to assess the differences between the present study groups and Bolton's original sample. A significant statistically difference was observed in both anterior and overall ratios between the normal occlusion of the present study and Bolton's original sample (Table V).

Table V - Comparison between the present study result and Bolton's mean values

\begin{tabular}{|c|c|ccc|}
\hline Ratio type & $\begin{array}{c}\text { Sample } \\
\text { size }\end{array}$ & Mean & SD & P-value \\
\hline Anterior ratio & & & & \\
\hline Present study & 104 & 78.37 & 2.54 & $<0.001^{\star}$ \\
\hline Bolton study & 55 & 77.2 & 1.65 & \\
\hline Overall ratio & & & & \\
\hline Present study & 104 & 92.79 & 7.43 & $0.044^{\star}$ \\
\hline Bolton study & 55 & 91.3 & 1.91 & \\
\hline
\end{tabular}

* Significant at $p \leq 0.05$, SD - Standard deviation

\section{DISCUSSION}

In this present study, tooth size ratios among university Sudanese students were investigated. 
Most of the other investigators derived their sample from an orthodontic population [21,2628]. In a few studies, the samples comprised a normal population chosen from schoolchildren $[3,29]$. This study determined its sample from university students.

The Sudanese population consisted of different ethnic groups, students came to the university from different parts of Sudan, so this sample gives good representation to the Sudanese population. The age range of the sample in this study was 16-26 yrs. According to Doris et al. [1] and N. Puri et al. [30], the young age group is ideal because of less mutilation and less attrition in most subjects, so their effect on mesiodistal tooth width would be minimum.

Males are consistently found to have larger teeth than females [31,32]. Therefore, to avoid gender bias on measurement outcome and to verify the presence of any sexual dimorphism, this study was presented with an equal ratio of male and female.

Racial variations in mesiodistal tooth width have been noted by previous researchers [31,3336]. Therefore, variations in the mesiodistal tooth width are likely to be population-specific. Furthermore, many clinicians are using Bolton analysis as their primary guide for predicting tooth-size discrepancies. However, the generalized use of the Bolton analysis and the proposed values for a harmonious dentition are under discussion and might not be valid for other populations [37]. For this possible ethnic variation, this study will provide data that can help clinicians to treat Sundanese orthodontic patients.

Our measurements were obtained from the plaster cast. Traditional irreversible hydrocolloids were generally stable when poured immediately [38]. Dental cast provides information about teeth size, shape, alignment, and rotations, and it also gives a clue about arch form, symmetry, and occlusal relationship [39].
The high range of values in Bolton ratios in the present sample (Table III) demonstrates variability. Despite all the selected subjects had a Class I canine and molar relationship with good occlusion, this variation might be attributed to compensation of tooth size ratio by an inclination of the teeth to create a harmonious occlusion, or it was merely indicative of the type of population. The high range also reflects the well-known multi-ethnic character of Sudanese people. Ethnic identity is highly fluid in Sudan and depends upon the criteria by which individual groups of Sudanese distinguish themselves from other groups.

The results of this investigation showed that there were no statistically significant differences between males and males for the anterior and overall ratios (Table III). Although the tooth size ratios for males were larger, the differences were small. This finding agrees with some studies $[11,15,16,19,20]$. However, other studies showed a gender difference in the overall ratio among different populations, suggesting that gender difference may also be populationspecific $[12,40,41]$.

In this study, significant differences in tooth size ratio between the examined Sudanese population and Bolton's overall ratios were found (Table IV), both overall and the anterior ratios were greater in the Sudanese sample than Bolton's sample. This finding might be due to differences in the sample population and the ethnic groups. This scenario is similar to that reported by Smith et al., who studied the Bolton's inter-arch ratio for three population groups, namely, Blacks, Hispanics, and Whites. They concluded that inter-arch tooth size relationships are population and gender specific and also in line with Lavelle [13] who found that the overall and the anterior ratios were greater among the black's race than the Caucasian race. However, our finding disagrees with the studies of Hashim et al. [4] and Ismail et al. [21] in the Sudanese population. Hashim et al. [4] conducted a study 
in the Sudanese population to establish a Bolton's ratios among 60 high school students (30 males and 30 females). They found no significant difference in tooth-size ratios between their study and Bolton's and also between both genders. Ismail et al. [21] surveyed 196 Sudanese male and female subjects presenting Class I normal occlusion, class I, II, and III malocclusions. The study aimed to establish a tooth-size ratio and compare the result with Bolton's mean values and also between both sexes. They found that no significant difference between the mean values of the overall and anterior ratio of their study and Bolton's and also between both genders. The differences in the study population and sample size between our study and these studies $[4,21]$ could account for these dissimilar findings.

(Table VI) compares the anterior and overall tooth size ratios of the present study with other populations. A review of the literature shows that significant differences exist among the various ethnic groups. Therefore, tooth size ratios have been established for different ethnic and racial groups.

The clinical significance of this study reveals that Bolton's tooth size ratios do not apply to the Sudanese population. It also confirms that no relevant gender dimorphism exists between male and female Sudanese subjects. However, limitations of the study should be noted, because of the time limit, this study was conducted on students attending AL-Neelain University. Therefore, a firm conclusion is challenging to draw. Thus, further investigations with a large sample collected from the different parts of Sudan are required.
Table IV - Anterior and overall tooth size ratios in different populations

\begin{tabular}{|c|c|c|c|}
\hline Population & Author & $\begin{array}{l}\text { Anterior } \\
\text { ratio\% }\end{array}$ & $\begin{array}{l}\text { Overall } \\
\text { ratio\% }\end{array}$ \\
\hline Sudan [Present Study] & Mustafa et al. (2020) & 78.37 & 92.79 \\
\hline Sudan [4] & Hashim etal. (2015) & 76.9 & 90.8 \\
\hline Sudan [21] & Ismail et al. (2015) & 77.46 & 91.47 \\
\hline Egyptian [42] & Al-Duliamy et al.(2016) & 78.85 & 91.6 \\
\hline Iraqi [42] & Al-Duliamy et al. (2016) & 78.72 & 91.23 \\
\hline Syrian [43] & Nourallaha et al.(2005) & 78.99 & 92.26 \\
\hline Yemen [31] & Al-Gunaid etal.(2012) & 78.36 & 92.49 \\
\hline Emiratis[44] & $\begin{array}{l}\text { Mohammad et al. } \\
\text { (2018) }\end{array}$ & 77.54 & 91.41 \\
\hline Saudi Arabian [20] & $\begin{array}{l}\text { Al-Tamimi and Hashim } \\
\text { (2005) }\end{array}$ & 77.4 & 91.4 \\
\hline White Americans [10] & Bolton (1958) & 77.2 & 91.3 \\
\hline White Americans [12] & Smith et al. (2000) & 79.6 & 92.3 \\
\hline Black Americans [12] & Smith et al. (2000) & 79.3 & 93.1 \\
\hline Spanish [12] & Smith et al. (2000) & 80.5 & 93.4 \\
\hline Spanish [15] & Paredes etal.(2006) & 78.32 & 91.97 \\
\hline Dominican [45] & Santoro et al. (2000) & 78.1 & 91.3 \\
\hline Peruvian [40] & Bernabéetal. (2004) & 78.09 & 91.33 \\
\hline Chinese [46] & Ta et al.(2001) & 77.5 & 90.9 \\
\hline Turkish [41] & Uysal etal. (2005) & 78.26 & 89.88 \\
\hline Turkish [11] & Akyalcin et al. (2006) & 78.15 & 91.34 \\
\hline Jordanian [3] & Al-Omarietal.(2008) & 78.6 & 92.2 \\
\hline Iranian [29] & Kachoei et al (2011) & 78.10 & 92.24 \\
\hline
\end{tabular}

\section{CONCLUSION}

1-The means of the anterior ratio and the overall ratio in the Sudanese sample were 78.37 (SD 2.54) and 92.79 (SD 7.43), respectively.

2-There were no significant differences in Bolton's ratio between males and females of the present study.

3-There were significant differences between the present study and Bolton's study for overall ratio and anterior ratio. 


\section{Conflict of Interest}

There is no conflict of interest

\section{Acknowledgment}

For all students who participated in this study.

\section{REFERENCES}

1. Golwalkar SA, Msitry KA. An evaluation of dental crowding in relation to the mesiodistal crown widths and arch dimensions. J Indian Orthod Soc. 2009;43(2):22.

2. Faruqui S, Fida M, Shaikh A. Comparison of tooth and arch dimensions in dental crowding and spacing. Pakistan Ort J. 2012:4(2):48-55.

3. Al-Omari IK, Al-Bitar ZB, Hamdan AM. Tooth size discrepancies among Jordanian schoolchildren. Eur J Orthod. 2008;30(5):527-31.

4. Hashim AaHA, Eldin A-HM, Hashim HA. Bolton tooth size ratio among Sudanese population sample: a preliminary study. J Orthod Sci. 2015;4(3):7782.

5. Bennett JC, McLaughlin RP. Orthodontic management of the dentition with the preadjusted appliance. Maryland: Mosby; 1997.

6. Crosby DR, Alexander CG. The occurrence of tooth size discrepancies among different malocclusion groups. Am J Orthod Dentofacial Orthop. 1989;95(6):457-61.

7. Mishra RK, Kafle D, Gupta R. Analysis of interarch tooth size relationship in nepalese subjects with normal occlusion and malocclusions. Int J Dent. 2019;2019:2761427.

8. Gilpatric WH. Arch predetermination: Is it practical? J Am Dent Assoc. 1923;10(7):553-72

9. Lundström A. Intermaxillary tooth width ratio and tooth alignment and occlusion. Acta Odontol Scand. 1955;12(3-4):265-92

10. Bolton WA. Disharmony in tooth size and its relation to the analysis and treatment of malocclusion. Angle Orthod. 1958;28(3):113-30.

11. Akyalçın S, Doğan S, Dinçer B, Erdinc AME, Öncağ G. Bolton tooth size discrepancies in skeletal Class I individuals presenting with different dental angle classifications. Angle Orthod. 2006;76(4):637-43.

12. Smith SS, Buschang $\mathrm{PH}$, Watanabe E. Interarch tooth size relationships of 3 populations:“Does Bolton's analysis apply?". Am J Orthod Dentofacial Orthop. 2000;117(2):169-74.

13. Lavelle C. Maxillary and mandibular tooth size in different racial groups and in different occlusal categories. Am J Orthod. 1972;61(1):29-37.

14. Freire SM, Nishio C, Mendes AdM, Quintão CCA, Almeida MA. Relationship between dental size and normal occlusion in Brazilian patients. Braz Dent J. 2007;18(3):253-7.

15. Paredes V, Gandia JL, Cibrian R. Do Bolton's ratios apply to a Spanish population? Am J Orthod Dentofacial Orthop. 2006;129(3):428-30

16. Nie Q, Lin J. Comparison of intermaxillary tooth size discrepancies among different malocclusion groups. Am J Orthod Dentofacial Orthop. 1999:116(5):539-44.

17. Araujo E, Souki M. Bolton anterior tooth size discrepancies among different malocclusion groups. Angle Orthod. 2003;73(3):307-13.
18. Uysal T, Memili B, Usumez S, Sari Z. Dental and alveolar arch widths in normal occlusion, class II division 1 and class II division 2. Angle Orthod. 2005;75(6):941-7.

19. Alkofide E, Hashim H. Intermaxillary tooth size discrepancies among different malocclusion classes: a comparative study. J Clin Pediatr Dent. 2002:26(4):383-7.

20. Al-Tamimi T, Hashim HA. Bolton tooth-size ratio revisited. World J Orthod. 2005;6(3):289-95.

21. Ismail MA, Abuaffan AH. Tooth size discrepancy among different malocclusion groups in Sudanese sample. Orthod Waves. 2015;74(2):37-41.

22. Poosti M, Jalali Ta. Tooth size and arch dimension in uncrowded versus crowded Class I malocclusions. J Contemp Dent Pract. 2007;8(3):45-52.

23. Moorrees CF, Reed RB. Correlations among crown diameters of human teeth. Arch Oral Biol. 1964;9:685-97.

24. Koo TK, Li MY. A guideline of selecting and reporting intraclass correlation coefficients for reliability research. J Chiropr Med. 2016;15(2):155-63.

25. Dahlberg G. Statistical methods for medical and biological students. Br Med J.1940;2(4158):358-9.

26. Freeman JE, Maskeroni A, Lorton L. Frequency of Bolton tooth-size discrepancies among orthodontic patients. Am J Orthod Dentofacial Orthop. 1996:110(1):24-7.

27. Othman S, Harradine N. Tooth size discrepancies in an orthodontic population. Angle Orthod. 2007;77(4):668-74.

28. Endo T, Shundo I, Abe R, Ishida K, Yoshino S, Shimooka S. Applicability of Bolton's tooth size ratios to a Japanese orthodontic population. Odontology. 2007:95(1):57-60

29. Kachoei M, Ahangar-Atashi M-H, Pourkhamneh S. Bolton's intermaxillary tooth size ratios among Iranian schoolchildren. Med Oral Patol Oral Cir Bucal. 2011;16(4):e568-72.

30. Puri N, Pradhan KL, Chandna A, Sehgal V, Gupta R. Biometric study of tooth size in normal, crowded, and spaced permanent dentitions. Am J Orthod Dentofacial Orthop. 2007;132(3):279.e7-14.

31. Al-Gunaid T, Yamaki M, Saito I. Mesiodistal tooth width and tooth size discrepancies of Yemeni Arabians: a pilot study. J Orthod Sci . 2012;1(2):40-5.

32. Singh S, Goyal A. Mesiodistal crown dimensions of the permanent dentition in North Indian children. J Indian Soc Pedod Prev Dent 2006:24(4):192-6.

33. Merz ML, Isaacson RJ, Germane N, Rubenstein LK. Tooth diameters and arch perimeters in a black and a white population. Am J Orthod Dentofacia Orthop. 1991;100(1):53-8

34. Dempsey Pa, Townsend G. Genetic and environmental contributions to variation in human tooth size. Heredity. 2001;86(6):685-93.

35. Proffit WR, Fields HW, Sarver DM. Contemporary orthodontics. Maryland: Mosby;2014.

36. Zuhair Murshid B, Hashim HA. Mesiodistal tooth width in a Saudi population: a preliminary report. Saudi Dent J. 1993;5(2).

37. MirzakouchakiB, Shahrbaf S, Talebiyan R. Determining tooth size ratio in an Iranian-Azari population. J Contemp Dent Pract. 2007;8(7):86-93.

38. Nassar U, Aziz T, Flores-Mir CJTJopd. Dimensional stability of irreversible hydrocolloid impression materials as a function of pouring time: a systematic review. J Prosthet Dent. 2011;106(2):126-33.

39. Moyers RE. Handbook of orthodontics. 2nd ed. Chicago: Medical; 1963.

40. Bernabe E, Major PW, Flores-Mir C. Tooth-width ratio discrepancies in 
a sample of Peruvian adolescents. Am J Orthod Dentofacial Orthop. 2004;125(3):361-5.

41. Uysal T, SariZ, Basciftci FA, Memili B. Intermaxillary tooth size discrepancy and malocclusion: is there a relation? Angle Orthod. 2005;75(2):208-13.

42. Al-Duliamy MJ, Othman SS, Hussien FA. Comparison of Bolton's ratios in a sample of Iragi and Egyptian populations. J Baghdad Coll Dent. 2016;28(4):172-5.

43. Nourallah AW, Splieth CH, Schwahn C, Khurdaji M. Standardizing interarch tooth-size harmony in a Syrian population. Angle Orthod .2005;75(6):996-9.
44. Mohammad MG, Din SN-u, Khamis AH, Athanasiou AE. Overall and anterior tooth size ratios in a group of Emiratis. Open Dent J. 2018;12:655-663.

45. Santoro M, Ayoub ME, Arthur Pardi V, Cangialosi TJ. Mesiodistal crown dimensions and tooth size discrepancy of the permanent dentition of Dominican Americans. Angle Orthod. 2000;70(4):303-7.

46. Ta TA, Ling JY, Hägg U. Tooth-size discrepancies among different occlusion groups of southern Chinese children. Am J Orthod Dentofacial Orthop. 2001;120(5):556-8.

Raja AbdAlgadir Mustafa

(Corresponding address)

Orthodontic department

Al Neelain University

Date submitted: 2020 Apr 03

Khartoum, Sudan

Accept submission: 2020 0ct 27 